\title{
Dwa kościoły, dwóch architektów, jedna sylweta - „styl narodowy" a zapożyczanie form w architekturze sakralnej II RP
}

\author{
Anna Tejszerska \\ https://orcid.org/0000-0001-7872-4496 \\ s.annat.sjk@wp.pl \\ Katedra Kształtowania i Projektowania Krajobrazu, Katolicki Uniwersytet Lubelski Jana Pawła II
}

\begin{abstract}
Streszczenie: Artykuł poświęcony jest zapożyczeniom form w architekturze sakralnej II RP. Dokonano w nim analizy porównawczej kościołów wzniesionych w odległych od siebie miejscowościach (diecezja pińska i łódzka), przypisywanych różnym autorom, a wykazujących znaczne podobieństwo formalne. Opracowanie stanowi jednocześnie próbę ustalenia faktycznego autorstwa budowli. Przedstawia także pokrótce powszechną w czasie budowy omawianych kościołów ideę poszukiwania „stylu narodowego", w którym zostały one ukształtowane i ukazuje podobne przykłady powielania form. Wywód oparto na archiwalnym materiale ikonograficznym - fotografiach z lat budowy, projektach oraz aktach pomocnych w rekonstrukcji życiorysu zawodowego twórców. Celem publikacji jest także przybliżenie postaci brzeskiego architekta Bronisława Nielubowicza i wątków pracy twórczej, które w ramach jej przygotowania udało się autorce ustalić.
\end{abstract}

Słowa kluczowe: architektura sakralna II RP, styl narodowy w architekturze, architektura dwudziestolecia międzywojennego, Bronisław Nielubowicz architekt

\section{Słowem wstępu}

Początki okresu dwudziestolecia międzywojennego w Polsce naznaczone były intensywną działalnością budowlaną związaną z odbudową kraju po stratach wojennych i kształtowaniem struktur materialnych odradzającego się państwa. Wzmożony ruch budowlany w zakresie obiektów sakralnych, wynikający dodatkowo z wieloletnich zaległości z okresu zaborów, wyznaczała w zasadniczej mierze społeczna działalność komitetów budowy i nakłady finansowe miejscowych społeczności. Nieodłącznie towarzyszące inwestycjom trudności ekonomiczne okresu powojennej odbudowy i kryzysu lat 30. skłaniały do poszukiwanie oszczędności tak w sferze budowlanej jak i w zakresie pozyskiwania projektów, co niejednokrotnie prowadziło do korzystania z jednakowych planów w kilku miejscowościach jednocześnie.

\section{Kontekst architektoniczno-ideowy}

W pierwszych latach budowy i odbudowy II Rzeczypospolitej architekci poczuwający się do odpowiedzialności za kształtowanie ojczystego krajobrazu, kontynuowali rozpoczęte w okresie niewoli poszukiwanie i wdrażanie form "stylu narodowego". Idea była próbą wprzęgnięcia architektury w dzieło ochrony, podtrzymywania i ugruntowywania tożsamości narodowej w zakresie wizualnym. Jej celem było kształtowanie rodzimego, swojskiego krajobrazu. W okresie zaborów stanowiła antidotum na przejawy przestrzennej rusyfikacji i germanizacji kraju, znajdujących wyraz w celowo zamierzonych inwestycjach budowlanych zaborców na terenach Polski. Po odzyskaniu niepodległości kształtowanie "stylu narodowego" wiązało się z utwierdzaniem tożsamości i odpowiedzialnością za odbudowę państwa, którego architektura potwierdzała przynależność ziem do Rzeczypospolitej, 
dawała poczucie "mieszkania we własnym domu”, w kraju o długiej tradycji kulturowej. Sięgano zatem do wzorców, które zdawały się architektom najbardziej charakterystyczne dla rodzimego budownictwa, a jednocześnie przypominały epokę sprzed okresu niewoli. Nawiązywano i przetwarzano wątki renesansowe, barokowe ze szczególnym sentymentem wykorzystując model polskiego dworu. W okresie budowy i odbudowy II RP idea "stylu narodowego" znalazła odzwierciedlenie w licznych obiektach sakralnych", budynkach użyteczności publicznej - szkołach, dworcach, urzędach państwowych ${ }^{2}$ oraz mieszkaniowych ${ }^{3}$, w szczególności w całościowo zaprojektowanych architektoniczno-urbanistycznych założeniach kolonii urzędniczych i wojskowych.

\section{Kontekst eklezjalny}

Początki okresu dwudziestolecia międzywojennego stanowią czas organizacji struktury administracyjnej II Rzeczypospolitej, także w zakresie podziału terytorialnego kościelnych metropolii. W obrębie Kościoła rzymskokatolickiego powołano wówczas do istnienia kilka nowych diecezji; w tym wyróżniającą się pod względem liczebności parafii diecezję łódzką (średnio 7480 wiernych ${ }^{4}$ ) oraz charakteryzującą się najmniejszą statystycznie liczbą parafian (1345), a jednocześnie wielką rozległością poszczególnych jednostek $\left(368 \mathrm{~km}^{2}\right)$ - diecezję pińską ${ }^{5}$. Oba uwarunkowania ciążące na wspomnianych diecezjach skłaniały lokalną społeczność i jej duchownych do podejmowania licznych inwestycji, służących zagęszczeniu sieci parafialnej. Poza szeregiem przykładów ilustrujących ogólny obraz budownictwa przedmiotowego okresu w artykule zaprezentujemy dwa wzniesione w wymienionych diecezjach obiekty sakralne - kościół Najświętszego Serca Pana Jezusa w Peliszczach (diec. pińska) oraz Jana Chrzciciela na Nowym Złotnie (diec. łódzka), które mimo znaczącej odległości przestrzennej łączy ewidentne podobieństwo formalne. Podobieństwo zbyt ścisłe by łączyć je jedynie z powszechnie panującą tendencją stylową.

\section{Diecezja pińska - uwarunkowania}

Nowoerygowana diecezja pińska powstała z części włączonej w granice II Rzeczypospolitej diecezji mińskiej oraz południowych terenów diecezji wileńskiej. Rozciągając się na obszarze trzech województw: poleskiego, nowogródzkiego i białostockiego, zajmowała powierzchnię ponad 50 tysięcy $\mathrm{km}^{2}{ }^{6} \mathrm{~W}$ momencie erekcji na jej terenie znajdowało się zaledwie 118 kościołów parafialnych, 18 filialnych oraz 111 kaplic i oratoriów ${ }^{7}$. Według spisu powszechnego przeprowadzonego w 1931 roku w granicach diecezji mieszkało ponad milion siedemset tysięcy osób, z czego znaczącą większość - 71,2 \% - stanowili prawosławni, podczas gdy liczba katolików

1 A. Tejszerska, Styl narodowy w architekturze sakralnej Polski Odrodzonej (1918-1939), Wydawnictwo KUL, Lublin 2019.

2 M. Pszczółkowski, Architektura użyteczności publicznej II Rzeczypospolitej 1918-1939. Forma i styl, Księży Młyn, Łódź 2014.

3 M. Rozbicka, Małe mieszkanie z ogrodem w tle w teorii i praktyce popularnego budownictwa mieszkaniowego w międzywojennej Polsce, Prace Naukowe Politechniki Warszawskiej, Seria Architektura, Warszawa 2008.

4 Największa łódzka parafia pw. Wniebowzięcia Najświętszej Maryi Panny liczyła 75000 wiernych. M. Różański, Organizacja terytorialna diecezji łódzkiej w latach 1920-1925, [w:] "Łódzkie Studia Teologiczne” 2015, nr 24/2, s. 87; Elenchus Lodzensis 1922, s. 17.

5 B. Kumor, Projekty reorganizacji Kościoła polskiego w latach 1918-1925, [w:] „Śląskie Studia Historyczno-Teologiczne” 1975, nr 8, s. 161. Diecezja łódzka została powołana w 1920 roku bullą „Christi Domini qui esse bonum pastorem”, natomiast diecezję pińską erygowano przy ustaleniu ostatecznego podziału terytorialnego Kościoła II RP bullą „Vixdum Poloniae unitas” z 1925 roku. Wartości liczbowe przytaczane przez Bolesława Kumora nieznacznie różnią się od podanych w Roczniku statystycznym (Kościół katolicki w Polsce 1918-1990. Rocznik statystyczny, red. L. Adamczuk, W. Zdaniewicz, Główny Urząd Statystyczny, Zakład Socjologii Religii SAC, Warszawa 1991, s. 107), niemniej wskazują na te same dysproporcje.

6 Kościół katolicki w Polsce 1918-1990..., op. cit., s. 107; M. Hałaburda M., Diecezja pińska (1925-1939). Rys historyczny, [w:] „Textus et Studia” 2017, $\mathrm{nr}$ 2(10), s. 98.

7 M. Hałaburda, Diecezja pińska (1925-1939)..., op. cit., s. 104, za: Elenchus Pinsci 1926, s. 82. Tenże autor w innej publikacji, powołując się na tą samą pozycję międzywojenną podaje nieznacznie wyższe liczby: 123 kościoły parafialne, 20 filialnych oraz 119 kaplic i oratoriów. Schematyzmy Diecezji Pińskiej (1926-1939), „Archiwa, Biblioteki i Muzea Kościelne” 2019, nr 112, s. 153, za: Elenchus Pinsci 1926, 30-76, 82. 
wszystkich obrządków nieznacznie przekraczała 17\% ogółu wahając się w granicach $300-315$ tysięcy ${ }^{8}$. Niemniej, rozłożenie obu grup ludności nie było równomierne. Południowy obszar parafii kamienieckiej, na którym miejscowa ludność przystąpiła do budowy świątyni, będącej przedmiotem niniejszego opracowania obfitowała w wiernych wyznania rzymskokatolickiego stanowiących na owym terenie dwie trzecie ogółu. Wieś Peliszcze położona 10 km od Kamieńca Litewskiego liczyła ponad pół tysiąca katolików i dwustu pięćdziesięciu wyznawców prawosławia9.

Budowa kościołów rzymsko-katolickich na Kresach Wschodnich z racji zróżnicowania etnicznego tych regionów i powstających na tym tle konfliktów, traktowana była niejednokrotnie jako instrument podtrzymywania polskości. W tym też duchu wyrażał swoje poparcie dla komitetu budowy starającego się o zapomogę na dokończenie inwestycji, wojewoda poleski J. Krachelski ${ }^{10}$ „traktując zamierzenia mieszkańców wsi Peliszcze jako zdrowy i dodatni dla uregulowania życia miejscowego i uspołecznienia ludności odruch elementu polskiego..."11. Niemniej w przypadku Peliszcz warto zaznaczyć podkreślane przez miejscowych katolików zaangażowanie ludności prawosławnej i unickiej w budowę łacińskiej świątyni. „Należy się podziękowanie naszym współmieszkańcom i braciom w Chrystusie prawosławnym, za ich ofiarną pracę przy budowie fundamentów i zwózce materiałów budowlanych"12.

Przygotowania do budowy kościoła w Peliszczu, będącej oddolną inicjatywą miejscowej ludności, rozpoczęto w 1928 roku. O opracowanie projektu niewielkiej świątyni poproszono stacjonującego w pobliskim Brześciu, (nawiasem mówiąc mieszkającego w jednej z najsłynniejszych, z dużym rozmachem zaprojektowanej i zrealizowanej (1921-1939) urzędniczej kolonii mieszkaniowej, wzniesionej w "stylu narodowym"), absolwenta Wydziału Architektury Instytutu Inżynierów Cywilnych w Petersburgu (1907), ówczesnego radcę budowlanego w starostwie Brzeskim, architekta wojewódzkiego Bronisława Nielubowicza (1880-1995). Warto w tym miejscu wspomnieć, że w publikacjach ${ }^{13}$ rozpowszechniła się swego czasu błędna informacja, jakoby twórcą projektu kościoła w Peliszczach był Wincenty Henryk Wdowiszewski (1849-1906). Została ona sprostowana w późniejszych badaniach Marcina Zglińskiego ${ }^{14}$. Bronisław Nielubowicz, którego podpis widnieje na projektowej planszy, wykonał plany kościoła dla należącej do parafii w Kamieńcu Litewskim wsi Peliszcze w przyspieszonym tempie ${ }^{15}$ i za połowicznym wynagrodzeniem ${ }^{16}$.

8 Przewaga obrządków wschodnich była znamienna cechą obszaru województwa poleskiego i diecezji pińskiej. Pińsk był jednocześnie stolica eparchii greckokatolickiej (pińsko-turowskiej), a pomiędzy rokiem 1795 a 1799 i od 1925 stolicą diecezji rzymskokatolickiej. W zachodniej części województwa poleskiego wydzielona była unicka eparchia włodzimiersko-brzeska. Jednakże w okresie zaborów w wyniku kolejnych akcji kasujących unię cerkiewną (w latach 1793-1796, 1839 i 1875) została ona niemalże unicestwiona. W. Kołbuk, Kościoły wschodnie w Rzeczypospolitej około 1772 roku: struktury administracyjne. Wspólnoty Religijne i Narodowe w Rzeczypospolitej w Drugiej Połowie XVIII wieku, t. 2. Instytut Europy Środkowo-Wschodniej, Lublin 1998. Niemały odsetek stanowili także wyznawcy religii mojżeszowej - przeciętnie 10\%, a w stolicy diecezji nawet 80\%. M. Hałaburda, Diecezja pińska (1925-1939)..., op. cit., s. 98, 101.

9 Skorowidz miejscowości Rzeczypospolitej Polskiej opracowany na podstawie wyników Pierwszego Powszechnego Spisu Ludności z dn. 30 września 1921 r. i innych źródeł urzędowych, t. 8: Województwo poleskie, Główny Urząd Statystyczny Rzeczypospolitej Polskiej, Warszawa 1924, s. 13. W spisie wieś występuje pod nazwą Piliszcze, Marcin Zgliński potwierdza, iż niejednokrotnie w różnych źródłach w ten sposób była zapisywana. M. Zgliński, Kościót parafialny pw. Najświętszego Serca Pana Jezusa w Peliszczach, [w:] Kościoły i klasztory Rzymskokatolickie dawnego województwa brzeskolitewskiego, t. 2, Międzynarodowe Centrum Kultury, Kraków 2014, s. 223.

10 Ojciec pozującej do posągu warszawskiej syrenki poetki i autorki piosenki „Bagnet na broń” - Krystyny Krachelskiej (1914-1944).

11 AAN, Sygn.: 2/14/0/5/719, k. 204-205.

12 Peliszczanin, Budowa kościoła w Peliszczach, "Polesie”, 1930, nr 22, s. 7. Zapewne, do takiego stanu rzeczy przyczyniała się postawa proboszcza miejscowej parafii w Kamieńcu Litewskim, który "będąc gorącym i szczerym patriotą polskim, był również wielkim propagatorem zbliżenia i zgodnego współżycia ludności polskiej i białoruskiej, rodzin prawosławnych i „polskich” - jak powszechnie określano ludzi należących do wyznania rzymsko-katolickiego". A. Paszkowicz, Historia budowy kościoła pw. Najświętszego Serca Jezusowego i Serca Maryi w Peliszczach, „Echa Polesia” 2011, nr 3(31), s. 8.

13 A.L., Nitsch, Leksykon architektów i budowniczych Polaków oraz cudzoziemców w Polsce działajacych, Warszawa (bdw), mps ISPAN, t. 12, s. 23-24; I. Dziemjaniuk, R. Konowaluk, Parafia Najświętszej Maryi Panny Królowej Korony Polskiej na Kijówce w Brześciu n/Bugiem, [w:] „Echa Polesia” 2007 nr 4(16), s. 38; A. Oleńska, M. Zgliński, Polesie jako region artystyczny w dawnej Rzeczypospolitej. Uwagi po pięciu latach inwentaryzacji kościołów i klasztorów rzymskokatolickich województwa brzesko-litewskiego, [w:] Stan badań nad wielokulturowym dziedzictwem dawnej Rzeczypospolitej, red. Walczak W., Łopatecki K., t. IV, Instytut Badań nad Dziedzictwem Kulturowym Europy, Białystok 2013, s. 123, 134.

14 M. Zgliński, Kościót parafialny pw. Najświętszego Serca Pana Jezusa w Peliszczach, op. cit., s. 229.

15 Projekt datowany na 29 stycznia 1929

16 A. Paszkowicz, Historia budowy kościoła..., op. cit., s. 9. Warto w tym miejscu zauważyć, że Nielubowicz był nie tylko brzeskim architektem wojewódzkim, ale także właścicielem majątku w Klukowiczach leżących w obrębie kamienieckiej parafii. Stąd zarówno skierowanie doń prośby o wykonanie projektu, jak i ulgowe potraktowanie opłaty wydają się tym mocniej uzasadnione. APB, Sygn.: 4/799/0/-/11. 


\section{Kościół w Peliszczach - forma architektoniczna}

Forma jednonawowej, nieznacznie przekraczającej powierzchnię $100 \mathrm{~m}^{2}$ świątyni, mimo jej niewielkich rozmiarów, każe ją ulokować na liście oryginalnych przykładów "stylu narodowego”. Dekoracyjne zwieńczenie niskiej, wysuniętej nieznacznym ryzalitem poza lico fasady, mieszczącej kruchtę wieży, kształtuje górną partię szczytu frontowej elewacji. Po obu stronach towarzyszą jej, kryjące dachowe połacie spływy ścianek szczytowych, wykończone podobnym kształtem okuciowego gzymsu. Na nietypowym dwupołaciowym dachu wieży, zakrytym od frontu wspomnianą szczytową ścianką, osadzono jakoby okrakiem wieżyczkę na sygnaturkę (Ryc. 1).

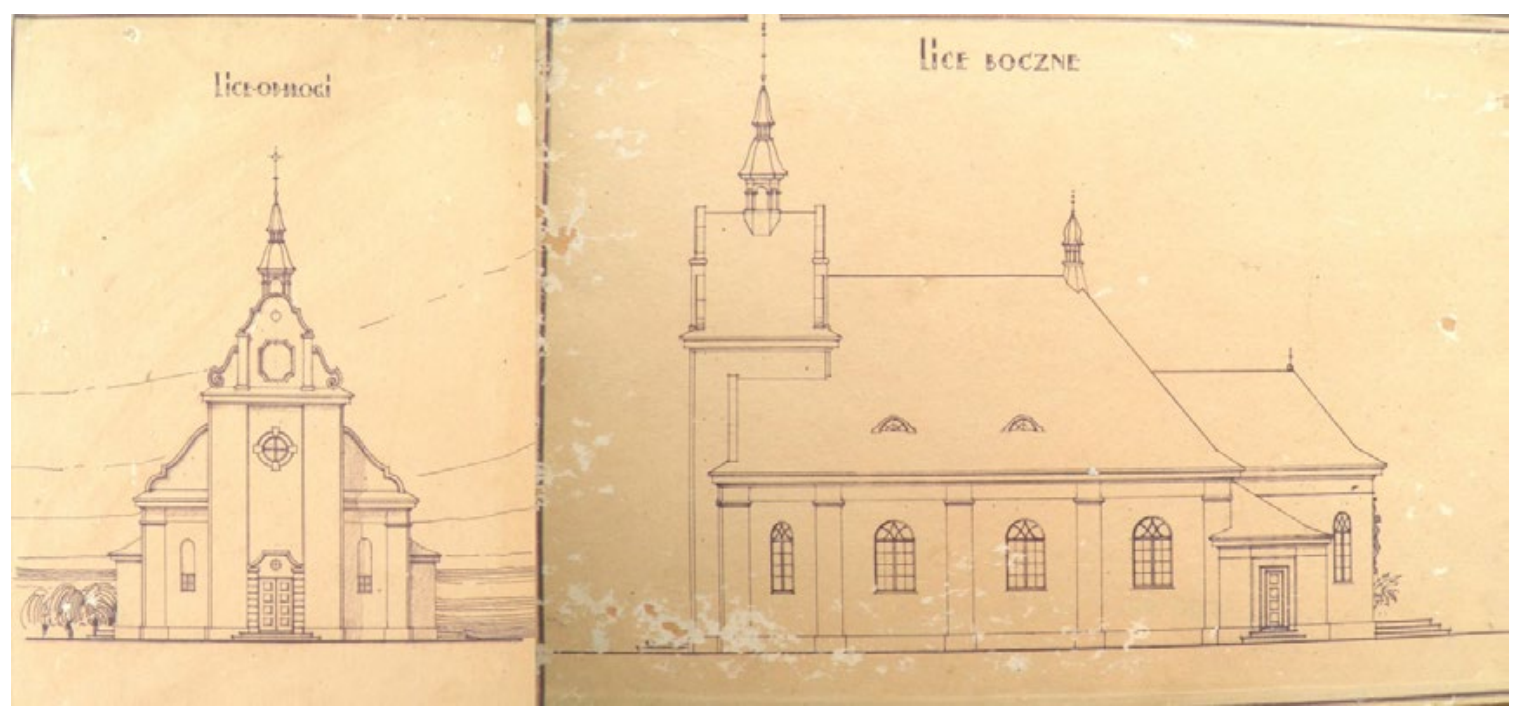

Ryc. 1. Projekt kościoła Najświętszego Serca Pana Jezusa w Peliszczach, arch. B. Nielubowicz 1929

Źródło: Archiwum Parafii pw. św. Apostołów Piotra i Pawła w Kamieńcu Litewskim, fot. M. Zgliński

Pośród wielu modeli kościołów wznoszonych w "stylu narodowym" tego typu rozwiązanie nie należy do powszechnych. Drugą jeszcze mniejszą wieżyczkę osadzono na końcu kalenicy wysokiego dachy kryjącego nawę. Prezbiterium i jego boczne aneksy przekryto, podobnie jak w większości ówczesnych kościołów tych rozmiarów, osobnymi, niższymi, dwu i trójpołaciowymi dachami. Szczegółem, którego znaczenie dla odmienności polskiego budownictwa wielokrotnie w swych wywodach o "stylu narodowym" podkreślał Stefan Szyller ${ }^{17}$, są kilkakrotnie tu zastosowane wydatne daszki okapowe kryjące gzymsy kordonowe. Kościół wybudowano zgodnie z przedstawionym przez architekta projektem w latach 1929-1934.

\section{Diecezja łódzka - uwarunkowania}

Niemal równolegle na zachodnich przedmieściach Łodzi - na Nowym Złotnie wznoszono podobnej wielkości, jednonawowy, jednowieżowy kościół pw. Jana Chrzciciela. Także tutaj, na obszarze powołanej z końcem 1920 r. diecezji łódzkiej, nie było jednolitej struktury wyznaniowej. Według danych z 1921 r., katolicy stanowili 53,5\% ludności biskupiego miasta ${ }^{18}$, tj. około 235 tys., wiernych objętych opieką duszpasterską w ramach zaledwie dziewięciu funkcjonujących tu, rozległych parafii ${ }^{19}$. Tak więc nawet w centralnych regionach II RP, pomimo znacznie większej gęstości zaludnienia i wyższego poziomu infrastrukturalnego zagospodarowania, odległość 
do najbliższego kościoła bywała problemem ${ }^{20}$. W 1930 roku w słowie skierowanym do wiernych przyszłej złotnieńskiej parafii ks. bp Wincenty Tymieniecki pisał:

„od chwili powstania diecezji Łódzkiej czynimy usilne starania, aby ułatwić wiernym zaspokajanie ich potrzeb religijnych. Od dawna już zwracało Naszą uwagę i było jedną z większych trosk, że mieszkańcy wiosek położonych na zachodniej stronie miasta Łodzi z powodu znacznych odległości od swych kościołów parafialnych i mając częstokroć bardzo utrudniony dostęp do tychże, nie mogli brać żywego udziału w życiu parafjalnem"21.

\section{Kościół na Nowym Złotnie - projekt i ostateczna forma architektoniczna}

Projekt kościoła na Nowym Złotnie ${ }^{22}$ wykonał w sierpniu 1926 roku łódzki architekt powiatowy Józef Kaban $(1886-1969)^{23}$. Jego forma wyraźnie nawiązywać miała do stylistyki art déco, uznawanej za jeden z ostatnich etapów kształtowania "stylu narodowego" w architekturze, w szczególności zdobnictwie i wyposażeniu wnętrz. Kościół otrzymał bardzo zbliżony do Peliszcz, a generalnie rzecz ujmując, typowy dla tej wielkości świątyń dwudziestolecia, rozkład rzutu (Ryc. 2, 3).

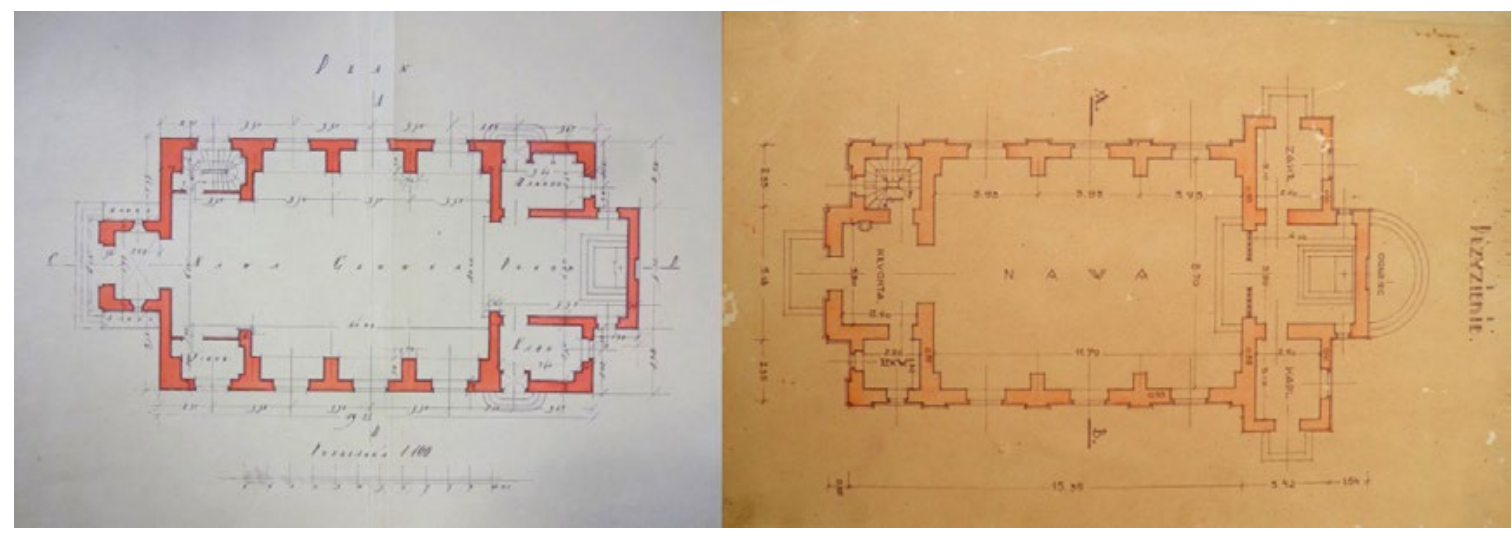

Ryc. 2. 3. Projekt kościoła pw. Jana Chrzciciela na Nowym Złotnie, arch. J. Kaban 1926; projekt kościoła Najświętszego Serca Pana Jezusa w Peliszczach, arch. B. Nielubowicz 1929

Źródła: AAN, Sygn.: 2/9/0/5.5/2908; Arch. Parafii św. Piotra i Pawła w Kamieńcu Litewskim, fot. M. Zgliński

Dostawioną do fasady, osiowo usytuowaną wieżę wieńczyć miała strzelista sygnaturka umieszczona na kulistym hełmie o wyraźnie modernistycznym charakterze ${ }^{24}$. Był on, rzec można, zmodernizowaną wersją zakończonego pseudobarokową latarnią kulistego hełmu zastosowanego przez Kabana w Bedoniu (1925-1933, proj. 1921). Indywidualnych znamion nadawała projektowi rozbudowana kompozycja frontonu utrzymana w duchu

20 Diecezja Łódzka rozpoczynała swą działalność z zaledwie 68 parafiami. Elenchus Lodzensis 1922, s. I-II. Ponad sześciotysięczna parafia w Konstantynowie, z której wypączkowała wspólnota na Nowym Złotnie należała do najliczebniejszych wspólnot podmiejskich. M. Różański, Organizacja terytorialna diecezji łódzkiej w latach 1920-1925..., op. cit., s. 100.

21 ADŁ: Sygn.: 64

22 Oficjalny tytuł zachowanego projektu brzmi: Projekt budowy kościoła w powiecie łódzkim, AAN, Sygn.: 2/9/0/5.5/2908

23 Autor wielu łódzkich budowli: Pałacu Biskupiego, Sądu Okręgowego, kościołów: Matki Bożej Zwycięskiej, Świętego Kazimierza na Widzewie, Świętego Franciszka z Asyżu na Rokiciu; od 1919 roku architekt diecezjalny. Stefański K., Kościoły Łodzi międzywojennej [w:] Sztuka w Łodzi 2. Materiaty sesji naukowej zorganizowanej przez Łódzki Oddział Stowarzyszenia Historyków Sztuki w dniach 8-9 października 2001 roku, red. Wróblewska-Markiewicz M., Stowarzyszenie Historyków Sztuki, Łódź 2003, s. 106.

24 W tym samym czasie - na przełomie lat 20. i 30. podobne zwieńczenie, choć nieco mocniej osadzone w tradycji, zastosowali Zygmunt Gawlik z Franciszkiem Mączyńskim w kościele pw. św. Pawła Apostoła w Zabrzu Pawłowie. 
art déco. Nawiązywały doń także portal boczny i oprawa pasyjnej sceny umieszczonej na zewnętrznej ścianie prezbiterium (Ryc. 4).

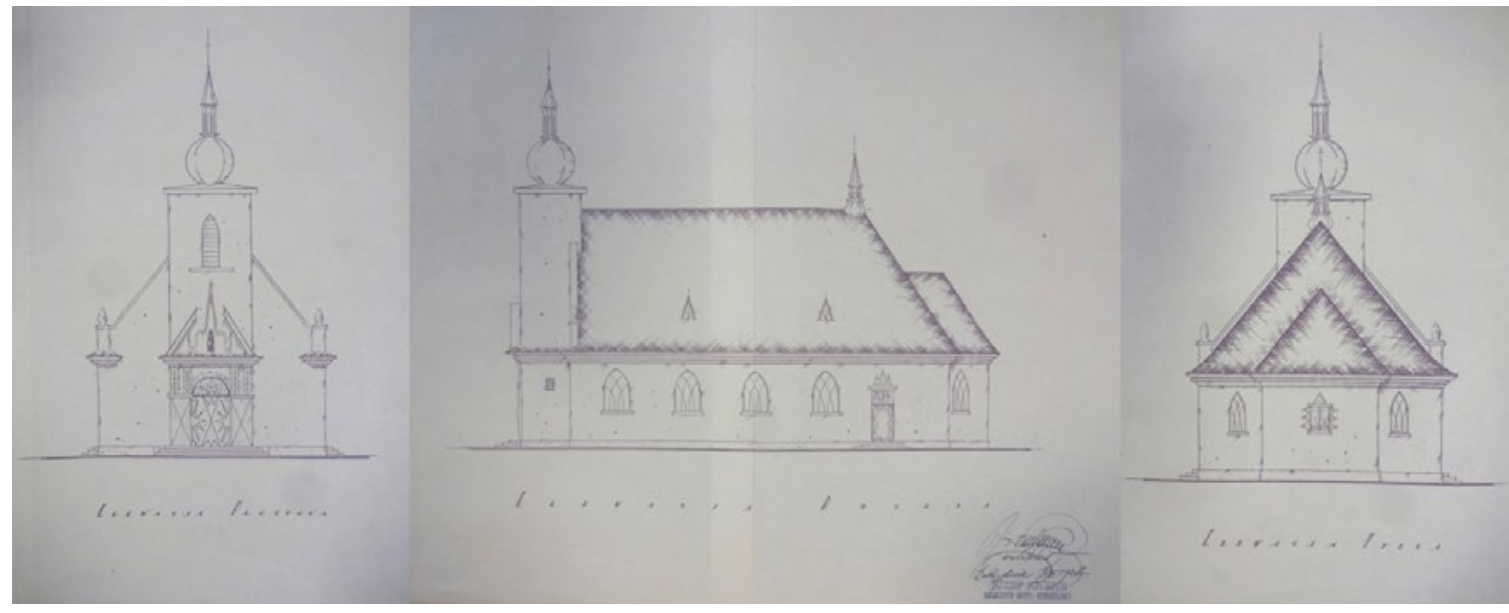

Ryc. 4. Projekt kościoła pw. Jana Chrzciciela na Nowym Złotnie, arch. J. Kaban 1926

Źródło: AAN, Sygn.: 2/9/0/5.5/2908

Mury łódzkiego kościoła doprowadzone zostały do wysokości okien do lata 1928 roku, kiedy to brak środków, pomimo szeroko zakrojonej akcji ich pozyskiwania ${ }^{25}$, spowolnił tempo inwestycji ${ }^{26}$. Do lata 1930 roku mury ścian bocznych dosięgły linii gzymsu, a wieża - poziomu na którym osadzony miał być kulisty hełm. Do tego momentu, sądząc po zachowanych fotografiach i widocznej na nich wyrazistej dekoracji portalu, budowę prowadzono zgodnie z projektem Kabana (Ryc. 5). Co wydarzyło się w przeciągu kilku kolejnych miesięcy, że ostatecznie górna część świątyni otrzymała kształt bliźniaczo podobny do kościoła w Peliszczach (Ryc. 6, 7) ${ }^{27}$, tak bardzo odmiennego w swym charakterze od projektu łódzkiego architekta?

Autorce nie udało się zrekonstruować pełnego biegu wydarzeń. Niemniej za czerpaniem wzorca z tego konkretnego obiektu przemawia nie tylko identyczna niemal dekoracja i kształt szczytu wieży oraz zwieńczeń bocznych ścianek szczytowych, czy dosłowna kopia umieszczonej na dachu wieży sygnaturki, ale także nietypowość rozwiązania polegającego na kryciu wieży dwuspadowym daszkiem, zasłonięcia jego połaci dekoracyjną ścianką szczytową, a nadto osadzania na tej konstrukcji wieżyczki na sygnaturkę.

Tego typu rozwiązanie, o innych jednak proporcjach, formie dekoracji i wyrazie artystycznym, znajdziemy jeszcze w zaprojektowanym przez Konstantego Jakimowicza kościele pw. św. Wawrzyńca w Jazgarzewie (1923-1928, proj. 1924). Samą koncepcję przekrycia wieży dwuspadowym daszkiem i zwieńczenia jej zdobnym szczytem (jednak bez dodatkowej sygnaturki) zastosował także Szyller w ramach neorenesnsowej przebudowy kościoła pw. św. Stanisława w Sieluniu (1913-1919) w ówczesnej diecezji płockiej. Rozwiązanie nie jest więc ewenementem, ale nie należy do popularnych i powszechnych. Nielubowicz zaś, z ustawieniem na dwuspadowym daszku frontowej wieży, nie tyle sygnaturki, co kopułki, miał już do czynienia przy projekcie prawosławnej cerkwi Świętych Sergiusza i Hermana Wałaamskich w Dubicy.

Mamy bardzo skąpe informacje na temat kariery zawodowej Nielubowicza. Wiemy że urodził się 21 czerwca 1880 r. w Krzemieńczuku, gdzie jego ojciec Władysław był dyrektorem szpitala. W 1907 roku ukończył studia na Wydziale Architektury Instytutu Inżynierów Cywilnych w Petersburgu. W latach dwudziestych mieszkał i pracował jako architekt wojewódzki w Brześciu. Z tego okresu pochodzi wspomniany powyżej, przechowywany w Archiwum Akt Nowych wykonany przez Nielubowicza projekt prawosławnej cerkwi w Dubicy nad Jeziorem 
Białym, w powiecie brzeskim, przeniesionej w 1926 r. do wsi Omieleniec w gminie Wierzchowice powiatu brzeskiego, pod nowym wezwaniem Podwyższenia Krzyża Świętego ${ }^{28}$.

We wspomnieniach rodzinnych przeczytamy jedynie o częstych bytnościach architekta w stolicy oraz należących do rodziny majątkach ziemskich w Klukowiczach i Leniewiczach ${ }^{29}$. Niemniej w Archiwum Państwowym w Łodzi zachowało się kilkadziesiąt - pochodzących z lat 1911-1914 - drobnych projektów dwu i jednokondygnacyjnych dobudówek do łódzkich posiadłości, sygnowanych przez Bronisława Nielubowicza jako architekta miasta Tomaszowa ${ }^{30}$. Projekty te, jako pochodzące z czasu zaborów opisane są cyrylicą. Niemniej, porównanie podpisów na nich umieszczonych z projektem kościoła w Peliszczach, zwłaszcza cyfr, inicjału imienia, proporcji liter i charakteru pisma nie budzi wątpliwości, że składała je ta sama osoba. Fakt działalności zawodowej Nielubowicza na stanowisku architekta miasta Tomaszowa potwierdza także jego Synowa, mieszkająca obecnie w Krakowie, której w tym miejscu bardzo serdeczne dziękuję za wszelkie udzielone informacje. Zachowana karta meldunkowa dowodzi, że architekt przynajmniej czasowo zamieszkiwał w Łodzi w latach 1920-192131. Akt zamieszkania wykazuje zgodność nie tylko imienia i nazwiska architekta, ale także daty jego urodzenia i imienia ojca, nie ma więc wątpliwości, że dokument mógłby dotyczyć innej osoby. Niezależny kontrakt potwierdza że w 1914 r. Nielubowicz wynajmował letnie mieszkanie w Inowłodzu nad Pilicą ${ }^{32}$. Tak więc związki architekta z Łodzią i jej okolicami są wielorako udokumentowane, choć nie ma bezpośredniego potwierdzenia, że bywał tu na przełomie lat 20. i 30.
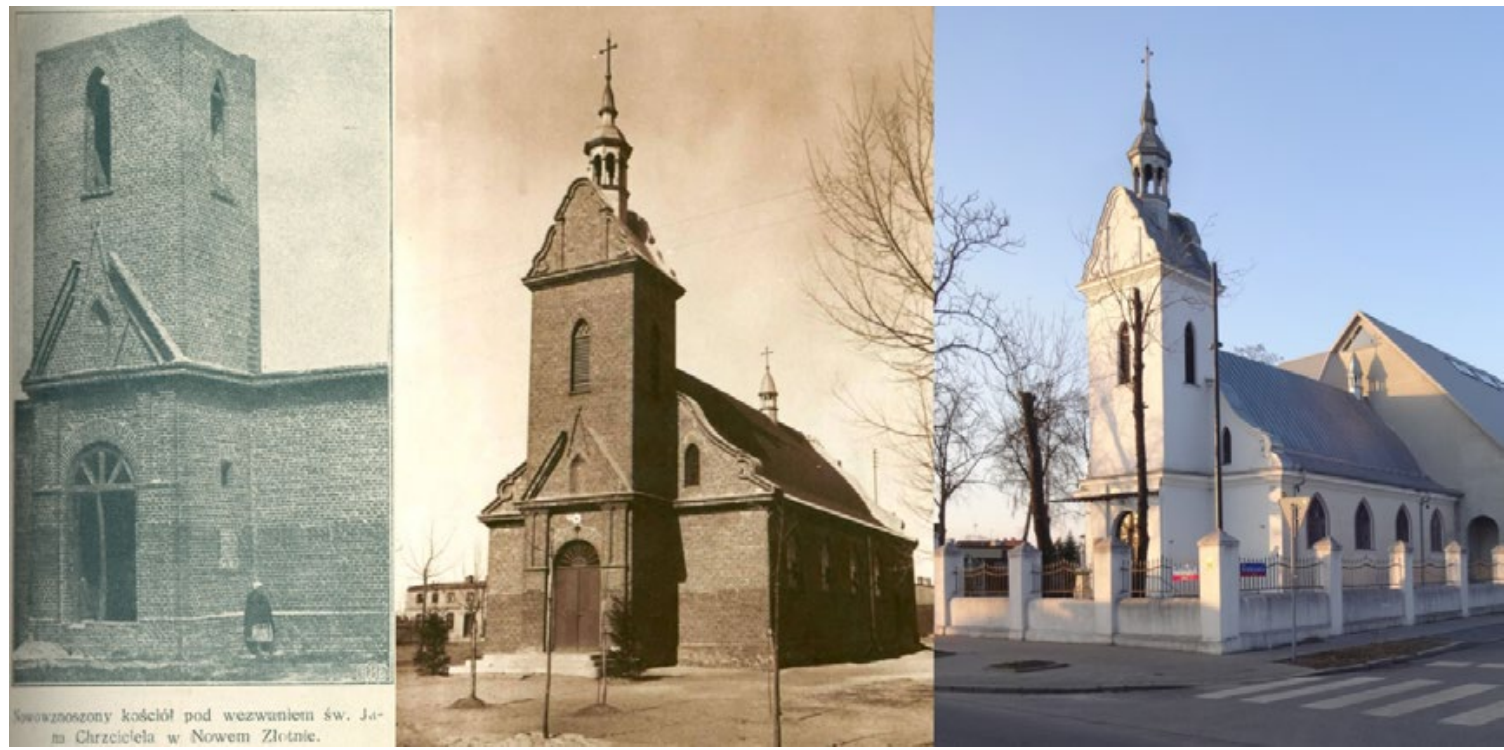

Ryc. 5. 6. 7. Kościół pw. św. Jana Chrzciciela na Nowym Złotnie: budowa 1930, w stanie surowym 1931, obecnie 2020 Źródła: Łódź w llustracji 1930; ze zbiorów Jacka Wystopa; fot autorka

Urodzony natomiast i rozpoczynający naukę w Krakowie Józef Kaban poza przerwanymi przez Wielką Wojnę studiami w Dreźnie, niemal całe swoje życie zawodowe związał z Łodzią. Jego dorobek i twórczy życiorys doczekały się licznych opracowań. Żadne jednak nie wspomina o związkach architekta z Kresami. Stąd przypuszczenie, że to raczej bywający z Łodzi Bronisław Nielubowicz przyszedł z pomocą Komitetowi Budowy łódzkiego kościoła. Mimo peryferyjnego położenia inwestycji, z racji szeroko zakrojonej akcji zbierania funduszy, do Komitetu Budowy, którego siedziba mieściła się w łódzkim Domu Ludowym, zaangażowano liczne grono 
ważnych osobistości miejscowego środowiska ${ }^{33}$. Jeśli tyko Nielubowicz miewał z nim w tym czasie bardziej czy mniej bezpośrednie kontakty, informacja o budowie i jej trudnościach z pewnością do niego dotarła..

Z relacji dotyczącej budowy kościoła w Peliszczach wiemy, że i ona na przełomie roku 1930 i 1931 przeszła chwilowy przestój z racji niewywiązania się firmy wykonującej „oryginalną konstrukcję sklepienia z wyginanych desek (...), która powiązana z więźbą dachową, oparta na zrębach ścian, eliminowała ciężar tradycyjnego sklepienia ceglanego"34. Może to właśnie koncepcja konstrukcji sklepienia przeważyła o zmianie projektu, na ten opracowany przez Nielubowicza. Wszak bardzo charakterystycznym elementem wnętrza kościoła na Nowym Złotnie było malowane drewniane sklepienie ${ }^{35}$.

\section{Kopiowanie form}

„Zapożyczanie" projektów kościołów i realizowanie ich w innych lokalizacjach było w dwudziestoleciu praktyką niejednokrotnie stosowaną. Gdy w okresie odbudowy kraju, a następnie wielkiego kryzysu gospodarczego lat trzydziestych niemal wszystkie komitety budowy borykały się z problemami finansowymi i trudnością uzbierania wystarczających środków, każda oszczędność (także ta związana z zakupem projektu) wydawała się istotna. Przykładowo w obrębie ówczesnej diecezji przemyskiej wzniesiono w dwudziestoleciu cztery bliźniaczo-podobne niewielkie świątynie: w Kuńkowcach (1932-1937, Ryc. 8) w wersji bezwieżowej, Ropience (1938-1939), Piątkowej-Pracówce (1936-1937; Ryc. 9) i Komarnikach (1936-1939) ${ }^{36}$. Kompilacja motywów własnych projektów była także domeną późnej twórczości Stefana Szyllera ${ }^{37}$.

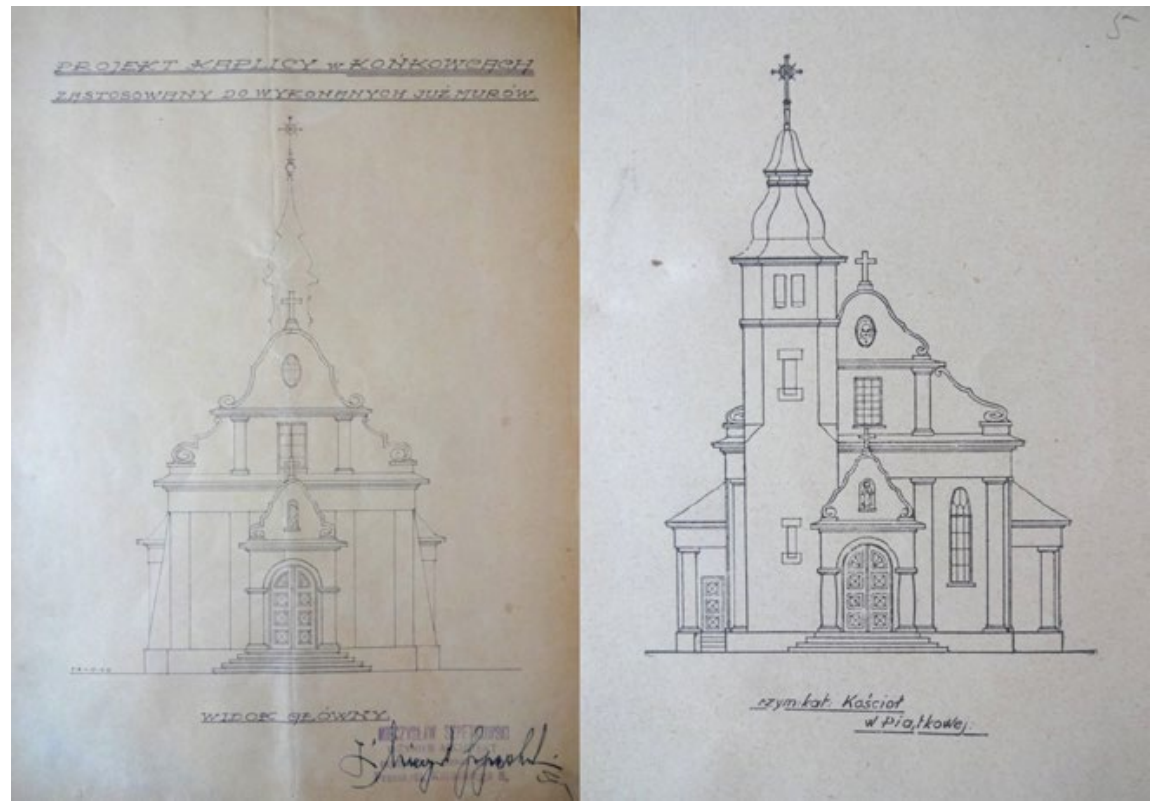

Ryc. 8. 9. Projekt kościoła w Kuńkowcach, arch. Mieczysław Szpetkowski; karta pocztowa - cegiełka na budowę kościoła w Piątkowej-Pracówce

Źródła: DALO, Sygn.: 1/29/1998; DALO, Sygn. $1 / 29 / 1481$

W ówczesnej mentalności powielanie form nie było postrzegane tak jednoznacznie pejoratywnie jak obecnie, zwłaszcza jeśli gwarantowało satysfakcjonującą formę estetyczną. Przykładowo w 1903 roku Arcybiskup Iwowski Józef Bilczewski (1860-1923), zlecił architektowi Tadeuszowi Obmińskiemu (1874-1932) wykonanie typowych projektów kościołów na 200, 400 i 600 osób, które nie tylko miały uprościć procedury, przyspieszyć

35 Fundi Instructi 1935. Trzeba jednak zaznaczyć, że jedyny dostępny autorce szkicowy projekt Józefa Kabana także nie zakładał murowanego sklepienia, jedynie płaski, drewniany strop. 
budowę i zmniejszyć jej koszty ${ }^{38}$ ale i „nie dopuścić do stawiania kościółków niestylowych" ${ }^{39}$. Projekty typowe były standardowo wykorzystywane w kolejnictwie. Nie odcinało się od nich także szkolnictwo.

\section{Konkluzja}

Kościół na Nowym Złotnie nie należy do najczęściej opisywanych inwestycji kościelnych łódzkiego dwudziestolecia, niemniej bywa w literaturze wzmiankowany. Nigdy jednak nie porównano go z kościołem w Peliszczach. Zazwyczaj prezentowany jest jako projekt Józefa Kabana, do czego z całą pewnością przyczynił się opublikowany na łamach "Architektury i Budownictwa” artykuł Jarosława Wojciechowskiego ${ }^{40}$. Obszerny tekst poświęcony całokształtowi budownictwa sakralnego dwudziestolecia międzywojennego, pośród wielu znaczących przykładów prezentował także niezrealizowany jeszcze projekt kaplicy na Nowym Złotnie autorstwa Kabana. Informacja w nim zawarta była później powtarzana, czasem uzupełniana wzmianką dotyczącą odstępstwa od projektu podczas realizacji ${ }^{41}$.

Kościół w Peliszczach po II wojnie światowej znalazł się w granicach ZSRR. Antykościelna polityka, rujnacja świątyń przystosowywanych do celów nie związanych z kultem, niejednokrotnie uwłaczających godności sakralnych obiektów, nie sprzyjała prowadzeniu badań nad architekturą kościołów regionu. Dopiero w ramach znakomitej serii Jana Ostrowskiego poświęconej sztuce sakralnej Kresów, Marcin Zgliński opublikował rozdział poświęcony kościołowi w Peliszczach ${ }^{42}$. Poleski kościół szczęśliwie pełnił funkcję sakralną przez cały okres władzy radzieckiej ${ }^{43}$, niemniej jego wyremontowana forma zewnętrzna nie zachowała charakterystycznych cech projektu Nielubowicza. Stąd porównanie obecnego wyglądu obu prezentowanych w artykule kościołów nie pozwala dostrzec ich ewidentnego niegdyś podobieństwa. Zwłaszcza, że i kościół na Nowym Złotnie nie przetrwał do naszych czasów w swej pełnej pierwotnej formie. Jego prezbiterium wchłonięte zostało przez doklejoną do korpusu halę nowego kościoła, nie nawiązującego w żaden sposób do form charakterystycznych dla architektury dwudziestolecia. Jedynie archiwalne dokumenty - projekty i fotografie wskazują na wspólne korzenie kompozycyjne obu prezentowanych w artykule budowli o urokliwych formach, stanowiących oryginalną interpretację prowincjonalnej architektury barokowej kształtowanej w duchu "stylu narodowego".

\section{Bibliografia}

[1] Dziemjaniuk I., Konowaluk R., Parafia Najświętszej Maryi Panny Królowej Korony Polskiej na Kijówce w Brześciu n/Bugiem, [w:] „Echa Polesia” 2007 nr 4(16), s. 37-39.

[2] Elenchus ecclesiarum et cleri dioecesis pinskensis pro anno Domini 1926, Pinsci 1926.

[3] Elenchus cleri secularis ac regularis Dioecesis Lodzensis pro Anno Domini 1922, Łódź 1922.

[4] Grad S., Rozwój sieci parafialnej w Łodzi w okresie międzywojennym, [w:] „Łódzkie Studia Teologiczne” 1999, nr 8, s. $365-377$.

[5] Hałaburda M., Diecezja pińska (1925-1939). Rys historyczny, [w:] „Textus et Studia” 2017, nr 2(10), s. $95-119$.

[6] Hałaburda M., Schematyzmy Diecezji Pińskiej (1926-1939), „Archiwa, Biblioteki i Muzea Kościelne” 2019, nr 112, s. $151-166$.

[7] Kołbuk W., Kościoły wschodnie w Rzeczypospolitej okoto 1772 roku: struktury administracyjne. Wspólnoty Religijne i Narodowe w Rzeczypospolitej w Drugiej Połowie XVIII wieku, t. 2. Instytut Europy Środkowo-Wschodniej, Lublin 1998.

[8] Kościót katolicki w Polsce 1918-1990. Rocznik statystyczny, red. Adamczuk L., Zdaniewicz W., Główny Urząd Statystyczny, Zakład Socjologii Religii SAC, Warszawa 1991.

38 K. Stefański Architekt lwowski - Tadeusz Obmiński (1874-1932). Twórczość w latach 1902-1914, [w:] Velis quod possis. Studia z historii sztuki ofiarowane profesorowi Janowi Ostrowskiemu, Wydawnictwo Towarzystwa Naukowego "Societas Vistulana”, Kraków 2016, s. 167.

39 Kurenda Konsystorza Metropolitarnego Lwowskiego Obrządku Łacińskiego 1903, Lwów 1903, s. 72-73; J. Ostrowski, Kościół parafialny pw. Matki Boskiej Królowej Polski w Zadwórzu, [w:] Kościoły i klasztory rzymskokatolickie dawnego województwa ruskiego, t. 11, Międzynarodowe Centrum Kultury, Kraków 2003, s. 344.

40 J. Wojciechowski, Kościót jako budowla, [w:] „Architektura i Budownictwo” 1927, nr 8-9, s. $227-260$.

41 K. Stefański Architekt Józef Kaban, [w:] „Kwartalnik Architektury i Urbanistyki” 1990, nr 3-4, s. 210.

42 Kościót parafialny pw. Najświętszego Serca Pana Jezusa w Peliszczach, op. cit.

43 A. Paszkowicz, Historia budowy kościoła..., op. cit., s. 4. 
[9] Kumor B., Projekty reorganizacji Kościoła polskiego w latach 1918-1925, [w:] „Śląskie Studia Historyczno-Teologiczne” 1975, nr 8, s. 155-162.

[10] Kurenda Konsystorza Metropolitarnego Lwowskiego Obrządku Łacińskiego 1903, Lwów 1903.

[11] Nowowznoszony kościót pod wezwaniem św. Jana Chrzciciela w Nowem Złotnie (fotografia, 1930), [w:] „Łodź w Ilustracji" 1930, nr 38, s. 3.

[12] Nielubowicz B., Moje kresowe szczenięce lata, [w:] „Echa Polesia” 2014, nr 3(43), s. 46-59.

[13] Nitsch A.L., Leksykon architektów i budowniczych Polaków oraz cudzoziemców w Polsce działających, Warszawa (bdw), mps ISPAN, t. 12.

[14] O budowę kościoła w Nowem Złotnie, [w:] „Rozwój” 1928, nr 199, s. 13.

[15] Oleńska A., Zgliński M., Polesie jako region artystyczny w dawnej Rzeczypospolitej. Uwagi po pięciu latach inwentaryzacji kościołów i klasztorów rzymskokatolickich województwa brzesko-litewskiego, [w:] Stan badań nad wielokulturowym dziedzictwem dawnej Rzeczypospolitej, red. Walczak W., Łopatecki K.., t. IV, Instytut Badań nad Dziedzictwem Kulturowym Europy, Białystok 2013, s. 109-134.

[16] Ostrowski J., Kościót parafialny pw. Matki Boskiej Królowej Polski w Zadwórzu, [w:] Kościoły i klasztory rzymskokatolickie dawnego województwa ruskiego, t. 11, Międzynarodowe Centrum Kultury, Kraków 2003, s. 341-348.

[17] Paszkowicz A. Historia budowy kościoła pw. Najświętszego Serca Jezusowego i Serca Maryi w Peliszczach, "Echa Polesia” 2011, nr 3(31), s. 3-22.

[18] Peliszczanin, Budowa kościoła w Peliszczach, „Polesie”, 1930, nr 22, s. 6-7.

[19] Pszczółkowski M., Architektura użyteczności publicznej Il Rzeczypospolitej 1918-1939. Forma i styl, Księży Młyn, Łódź 2014.

[20] Pszczółkowski M., Architektura szkolna /l Rzeczypospolitej (1918-1939), Księży Młyn, Łódź 2017.

[21] Różański M., Organizacja terytorialna diecezji tódzkiej w latach 1920-1925, [w:] „Łódzkie Studia Teologiczne” 2015, nr 24/2, s. 85-106.

[22] Rozbicka M., Małe mieszkanie z ogrodem w tle w teorii i praktyce popularnego budownictwa mieszkaniowego w międzywojennej Polsce, Prace Naukowe Politechniki Warszawskiej, Seria Architektura. Warszawa 2008.

[23] Skorowidz miejscowości Rzeczypospolitej Polskiej opracowany na podstawie wyników Pierwszego Powszechnego Spisu Ludności z dn. 30 września 1921 r. i innych źródet urzędowych, t. 8: Województwo poleskie, Główny Urząd Statystyczny Rzeczypospolitej Polskiej, Warszawa 1924.

[24] Stefański K., Architekt Józef Kaban, [w:] „Kwartalnik Architektury i Urbanistyki” 1990, nr 3-4, s. $207-215$.

[25] Stefański K., Kościoły Łodzi międzywojennej [w:] Sztuka w Łodzi 2. Materiały sesji naukowej zorganizowanej przez Łódzki Oddział Stowarzyszenia Historyków Sztuki w dniach 8-9 października 2001 roku, red. Wróblewska-Markiewicz M., Stowarzyszenie Historyków Sztuki, Łódź 2003, s. 103-118.

[26] Stefański K., Architekt lwowski - Tadeusz Obmiński (1874-1932). Twórczość w latach 1902-1914, [w:] Velis quod possis. Studia z historii sztuki ofiarowane profesorowi Janowi Ostrowskiemu, Wydawnictwo Towarzystwa Naukowego "Societas Vistulana", Kraków 2016, s. 163-170.

[27] Szyller S., O attykach polskich i polskich dachach wklęstych, druk Rubieszewskiego i Wrotnowskiego, Warszawa 1909.

[28] Szyller S., Czy mamy polską architekturę? Wydanie Koła Architektów w Warszawie, Warszawa 1916.

[29] Szyller S., Tradycya budownictwa ludowego w architekturze polskiej, księgarnia Gebethnera i Wolffa druk Rubieszewskiego i Wrotnowskiego Warszawa 1917.

[30] Tejszerska A., Styl narodowy w architekturze sakralnej Polski Odrodzonej (1918-1939), Wydawnictwo KUL, Lublin 2019.

[31] Wojciechowski J., Kościót jako budowla, [w:] „Architektura i Budownictwo” 1927, nr 8-9, s. 227-260.

[32] Wystop J., Kościół na Złotnie, cz. 2. [w:] „Złotniak” 2019, nr 7, s. 6.

[33] Zabawa na budowę kościoła, [w:] „Rozwój” 1928, nr 228, s. 12.

[34] Zgliński M. Kościót parafialny pw. Najświętszego Serca Pana Jezusa w Peliszczach, [w:] Kościoły i klasztory Rzymskokatolickie dawnego województwa brzeskolitewskiego, t. 2, Międzynarodowe Centrum Kultury, Kraków 2014, s. 223 -231.

\section{Źródła Archiwalne}

[35] AAN, Sygn.: 2/14/0/5/719: Archiwum Akt Nowych: Zespół: 2/14/0 Ministerstwo Wyznań Religijnych i Oświecenia Publicznego w Warszawie» Seria: 5 Departament V Wyznań» Jednostka 719 Budowa, remont i konserwacja kościołów i budynków parafialnych w poszczególnych parafiach, lit. Pa-Pi (t. XXIV). 1919-1939. 
[36] AAN, Sygn.: 2/9/0/5.5/2908: Archiwum Akt Nowych: Zespół: 2/9/0 Ministerstwo Spraw Wewnętrznych w Warszawie » Seria: 5.5 Dokumentacja techniczna » Jednostka: I 2908 Projekt budowy kościoła w powiecie łódzkim. 1926.

[37] AAN, Sygn.: 2/9/0/5.5// 2514: Archiwum Akt Nowych: Zespół: 2/9/0 Ministerstwo Spraw Wewnętrznych w Warszawie» Seria: 5.5 Dokumentacja techniczna» Jednostka: I 2514 Istniejąca cerkiew prawosławna w Dubicy, pow. Brzeskiego nad Białym Jeziorem, mająca być przeniesioną do wsi Omieleniec gminy Wierzchowice powiatu Brzeskiego. Projektował inż. arch. Bronisław Nielubowicz.

[38] ADŁ, Sygn.: 64: Archiwum Diecezjalne w Łodzi: Akta parafii Konstantynów, Sygn.: 64.

[39] AKDŁ, Sygn.: 138: Archiwum Diecezjalne w Łodzi:, Akta Parafii pw. Jana Chrzciciela Nowe Złotno, Fundi Instructi RP 1935.

[40] APB, Sygn.: 4/799/0/-/11: Archiwum Państwowe w Białymstoku: Zespół: 4/799/0 Starostwo Powiatowe Brzeskie Referat Rolnictwa i Reform Rolnych» Seria: bezpośrednio w zespole» Jednostka: 11 Sprawa parcelacji majątku Klukowicze, gm. Dmitrowicze, pow. brzeski, własność Bronisława Nielubowicza oraz małoletnich Jana i Hanny Nielubowiczów 1929-1938.

[41] APŁ, Sygn.: 39/221/0/4.12/24911: Archiwum Państwowe w Łodzi: Zespół: 39/221/0 Akta miasta Łodzi» Seria: 4.12 Wydział Ewidencji Ludności» Jednostka: 24911 Spis ludności Łodzi Nicińska - Niemicz 1916-1921.

[42] APŁ, Sygn.: 39/1/0 /4/18478: Archiwum Państwowe w Łodzi: Zespół: 39/1/0 Rząd Gubernialny Piotrkowski» Seria: 4 Wydział Budowlany» Jednostka: 18478 Kontrakt wynajmu mieszkania letniego przez inżyniera Nielubowicza od Bernarda Birencweiga w Inowłodzu.

[43] APŁ, Sygn.: 39/1/0 /4: Archiwum Państwowe w Łodzi: Zespół: 39/1/0 Rząd Gubernialny Piotrkowski» Seria: 4 Wydział Budowlany.

[44] DALO, Sygn.: 1/29/1998: Dierżawnyj Archiv Lvivskoi Obłasti: fond 1 Lwowski Urząd Wojewódzki, opis 29 Wydział komunikacyjno-budowlany - oddział budowlany, sprawa 1998 Powiększenie kościoła w Kuńkowcach w przemyskim powiecie.

[45] DALO, Sygn.: 1/29/1481: Dierżawnyj Archiv Lvivskoi Obłasti: fond 1 Lwowski Urząd Wojewódzki, opis 29 Wydział komunikacyjno-budowlany, oddział budowlany, sprawa 1481 Projekt budowy rzymskokatolickiego kościoła w Piątkowej w Dobromilskim powiecie. 